\title{
Aspect Regarding Plastic Deformations in Tibial Plateau Fractures
}

\author{
MARCEL MIHAI BERCEANU VADUVA ${ }^{1,2 \#, ~ H O R A T I U ~ P E T R E S C U 1,2 *, ~ R A M I ~ M U S A L L ~ A M ², ~ A B D O U L ~ F A T T A H ~ B O U S T A N I ~}{ }^{4}$, \\ MILAN VELIMIROVICI ${ }^{\sharp *}$, DANA EMILIA VELIMIROVICI ${ }^{1 *}$, MARIA RADA ${ }^{1}$, MATILDA RADULESCU $^{1}$, \\ DELIA MIRA BERCEANU VADUVA ${ }^{1}$ \\ 'University of Medicine and Pharmacy Victor Babes, 2 Eftimie Murgu Sq., 300041, Timisoara, Romania \\ ${ }^{2}$ Clinical Emergency County Hospital Pius Branzeu, 10 losif Bulbuca Bv., 300723, Timisoara, Romania \\ ${ }^{3}$ Clinical Emergency Pediatric Hospital Louis Turcanu, 2 Dr. Iosif Nemoianu Str., 300011, Timisoara, Romania \\ ${ }^{4}$ Royal Buckinghamshire Hospital, Buckingham Rd., Aylesbury HP 19 9AB, United Kingdom
}

\begin{abstract}
Our purpose was to study tibial plateau fractures considering the rise of their incidence, their potential immediate seriousness or late complications and their complexity. We realized a clinical-statistical study concerning the incidence of tibial plateau fractures taking in account critaeria like age, sex, mechanism of injury, fracture type and correlations between these. The study involves 126 patients, 98 (77.77\%) being treated surgically and 28 (22.22\%) conservatory between 2008-2016 in the I-st Clinic of Orthopaedics and Traumatology Timisoara. Approximately 2/3 of cases are of Schatzker type I, II and III. Type VI Schatzker occured in $5.78 \%$ of all, the mechanism of injury being split almost equal between road accidents and falls from height. Road accidents prevale as a causing circumstance of tibial plateau fractures. 2/3 of the tibial plateau fractures associate with other significant regional lesions. Bone lesions are not rarely underestimated by plain radiographs. Therefore evacuation of haemarthrosis (showing lipohaemarthrosis) and high performance imaging (CT, MRI) are often needed. In comparison to other fracture sites, imperfect reduction of tibial plateau fractures results more frequently in long term sequellae. Being frequently complex, comminuted fractures with associated regional lesions tibial plateau fractures raise the complexity of the medical act from establishing a complete diagnosis to the final therapeutic measures. For a correct and complete preoperatory diagnosis frequently high performance imaging is needed. Tibial plateau fractures significantly affect patients, the healthcare and social-economic system, the healing and rehabilitation.
\end{abstract}

Keywords: tibial plateau fractures, associated lesions, imaging

Tibial plateau fractures have always been and continue to be, to great extent, a real challenge for orthopeadic surgeons, due to regional anatomical features and frequent damage of the joint surface in a bear-weighting limb. Furthermore, the great variety of anatomical pathology of these fractures also urged us to conduct this study [1, 2,].

Treatment challenges are linked to the spongy and brittle characteristic of the proximal tibia, especially when the fracture lines are multiple and when they cause a local compression of the subchondral bone. The frequent compression of the articular cartilage / subchondral bone, tears of the meniscus and of the joint ligaments all endanger the perfect anatomical reduction, and can lead to early osteoarthritis and joint laxity, sometimes even after a primary correct surgical treatment [3-6].

For best results compression fractures should be elevated and the remaining free space filled with autologous bone grafts [7-10].

Tibial plateau fractures are often underestimated by plain radiographs, but they can be confirmed by evacuation of haemarthrosis (showing lipohaemarthrosis) and high performance imaging (CT, MRI) [11-13].

\section{Objective}

Our purpose was to study tibial plateau fractures considering the rise of their incidence, their potential immediate seriousness or late complications and their complexity. Most of these fractures are intraarticular, thereby generating most of the treatement challenges, as well as major medical and social costs.

\section{Experimental part}

Patients and methods

We realized a clinical-statistical study concerning the incidence of tibial plateau fractures taking in account critaeria like age, sex, mechanism of injury, fracture type and correlations between these.

The study involves 126 patients, $98(77.77 \%)$ being treated surgically and $28(22.22 \%)$ conservatory between 2008-2016 in the I-st Clinic of Orthopaedics and Traumatology Timisoara (fig. 1) [14-16].

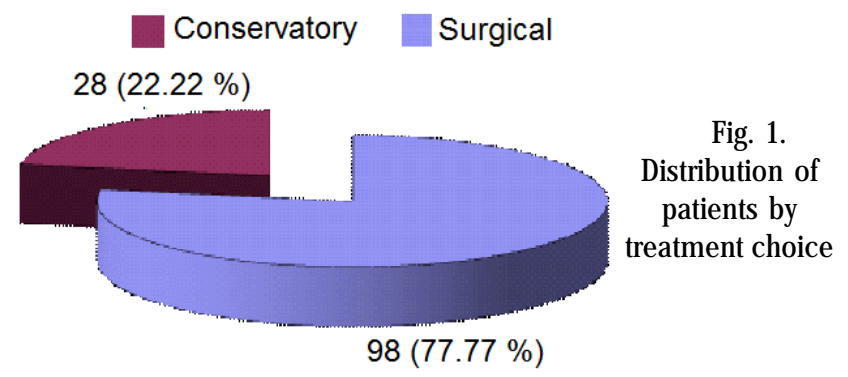

\section{Results and discussions}

Of the 126 patients, 68 (53.96\%) were male, and the rest of $58(46.03 \%)$ were female.

Out of the lot included in the study, 121 of the fractures occured in adulthood, and 5 cases were of patients in the growth period -epiphysiolysis.

We observed these fractures to prevale in men up to 50 years of age, and in women over this age. This finding is associated especially with a more impetuous lifestyle in men of younger ages, and a more intense decrease in bone density in menopausal women (fig. 2). 


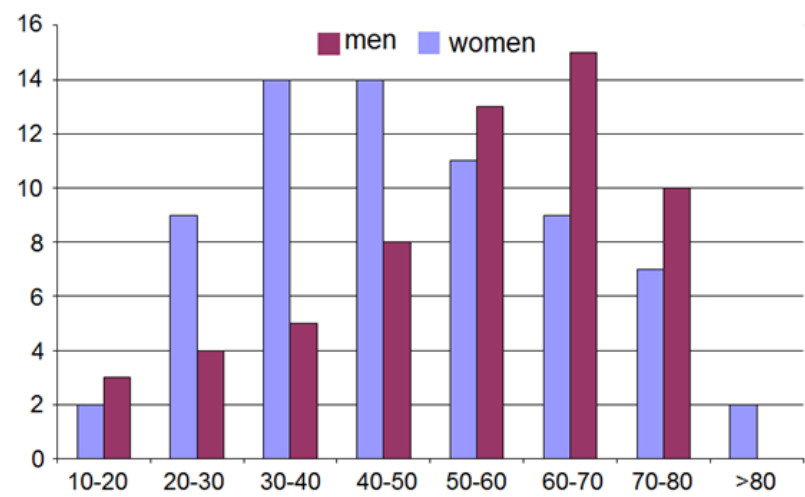

Fig. 2. Distribution of age groups and sex

Considering the mechanisms of injury, we observed road accidents to be the leading cause of tibial plateau fractures, whether betweens cars, between cars-pedestrians, or accidents involving two-wheel vehicles [1, 17- 19].

The second cause was the fall from low height or samelevel height, especially in elderly patients (14.28\%). This was closely followed by the third cause, falls from height $(12.69 \%)$, which occured mostly in young or middle-aged patients and happened as accidental falls in the home, in the workplace and even voluntary jump in the attempt to escape aggression (table 1) [15, 17].

Table 1

CIRCUMSTANCES OF FRACTURES

\begin{tabular}{|l|c|c|}
\hline Circumstances of fractures & Number & Percent (\%) \\
\hline Road accidents same height: stairs, & 18 & 57.14 \\
\hline $\begin{array}{l}\text { Falls from } \\
\text { sliding, torsion }\end{array}$ & 16 & 14.28 \\
\hline Falls from height & 8 & 12.69 \\
\hline $\begin{array}{l}\text { Direct injury (work accident, } \\
\text { aggression) }\end{array}$ & 6.34 \\
\hline Sports injuries & 6 & 4.76 \\
\hline Other causes & $\mathbf{1 2 6}$ & 4.76 \\
\hline Total & 100 \\
\hline
\end{tabular}

Considering the distribution of fracture types, we observed that Schatzker type I, II and III made up approximately 2/3 of cases. Type VI Schatzker occured in $5.78 \%$ of all, the mechanism of injury being split almost equal between road accidents and falls from height (table 2) [19].

Schatzer type I, II and III, observed in approximately 2/ 3 of cases, affected the external tibial plateau [18, 20]. This is linked to the physiological valgus of the knee (especially in women) and the external plateau being more exposed in case of accidents of all types, including road accidents. Other important factors are the lower bone density of the external plateau, its weaker trabecular structure, and the instinctive tendency to fall with the lower limbs slightly abducted.
Table 2

OCCURENCE OF TIBIAL PLATEAU FRACTURES (SCHATZKER CLASSIFICATION)

\begin{tabular}{|l|c|c|}
\hline Fracture type & Number & Percent (\%) \\
\hline Schatzker I & 23 & 19 \\
\hline Schatzker II & 35 & 28.92 \\
\hline Schatzker III & 21 & 17.35 \\
\hline Schatzker IV & 13 & 10.74 \\
\hline Schatzker V & 22 & 18.18 \\
\hline Schatzker VI & 7 & 5.78 \\
\hline Total & 121 & 100 \\
\hline
\end{tabular}

$23.96 \%$ $65.28 \%$

$10.74 \%$

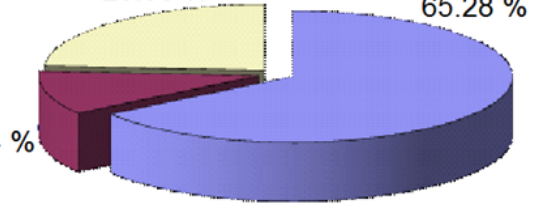

bicondylar

internal plateau

external plateau

Fig. 3. Distribution of fractures in adults - unicondylar / bicondylar

The external tibial plateau was affected in 79 cases (65.28\%), the internal one in 13 cases (10.74\%), and the bicondylar fracture occured in 29 cases (23.96\%). These findings are presented in figure 3.

Of the total 126 cases, 3 were open fractures $(2.38 \%)$ two of these were type I GA and one was type II GA, and the remaining 123 were closed fractures $(97.62 \%)$.

Studying the mechanism of injury correlated with the fracture type, we observed that most road accidents led to Schatzker type II fractures (17 cases), followed by Schatzker type V and III (14 cases, 13 cases respectively). Type $V$ fractures mostly occurred in high energy impacts (table 3) [21- 23].

Tibial plateau fractures are often complicated by association with other significant regional lesions in $2 / 3$ of the cases.

Not taking into account skin lesions, the most frequent associated regional lesions are: fractures of the fibula head, external meniscus tears, cruciate ligamentinjuries, internal meniscus tears, collateral ligament injuries and avulsion fractures of the tibial spines or rim (table 4).

From the total of associated regional lesions, external meniscus tears and fibula head fractures affected almost half of the patients (46\%) in almost equal parts. In 15 patients with meniscus lesions primary surgery for these was performed, and in 13 patients delayed surgery was performed. The following occurrence were injuries of the internal collateral and anterior cruciate ligaments, both with $5.55 \%$.

Correlations have been made between fracture type and associated regional injuries (table 5).

\begin{tabular}{|c|c|c|c|c|c|c|c|c|}
\hline & & Road & Fall & $\begin{array}{c}\text { Fall from } \\
\text { height }\end{array}$ & $\begin{array}{l}\text { Direct } \\
\text { injury }\end{array}$ & Sports & Other & Total \\
\hline \multirow{6}{*}{ 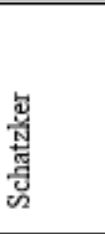 } & $\mathrm{I}$ & 11 & 2 & 3 & 2 & 3 & 2 & 23 \\
\hline & II & 17 & 6 & 4 & 3 & 2 & 3 & 35 \\
\hline & III & 13 & 8 & - & - & - & - & 21 \\
\hline & IV & 10 & 1 & 1 & 1 & - & - & 13 \\
\hline & $\mathrm{V}$ & 14 & 1 & 4 & 2 & - & 1 & 22 \\
\hline & VI & 4 & - & 3 & - & - & - & 7 \\
\hline \multirow{3}{*}{ 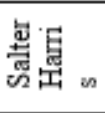 } & $\mathrm{I}$ & 1 & - & - & - & 1 & - & 2 \\
\hline & III & 1 & - & 1 & - & - & - & 2 \\
\hline & IV & 1 & - & - & - & - & - & 1 \\
\hline \multicolumn{2}{|c|}{ Total } & $7 / 2$ & 18 & 16 & 8 & 6 & 6 & 126 \\
\hline
\end{tabular}

Table 3

CORRELATION BETWEEN FRACTURE TYPE AND MECHANISM OF INJURY 
Table 4

ASSOCIATED REGIONAL LESIONS

\begin{tabular}{|l|c|c|}
\hline Associated lesions & Number & $\begin{array}{c}\text { Percent (\%) of } \\
\text { the total cases }\end{array}$ \\
\hline Fibula head fractures & 30 & 23.80 \\
\hline External meniscus (EM) tears & 28 & 22.22 \\
\hline Medial collateral lig. (MCL) lesions & 7 & 5.55 \\
\hline Anterior cruciate lig. (ACL) lesions & 7 & 5.55 \\
\hline Avulsion fractures of the tibial spines & 6 & 4.76 \\
\hline Lateral collateral lig. (LCL) lesions & 2 & 1.58 \\
\hline Posterior cruciate lig. (PCL) lesions & 2 & 1.58 \\
\hline Internal meniscus (II) tears & 2 & 1.58 \\
\hline Total & 85 & 66.62 \\
\hline
\end{tabular}

Fibula head fracture occurred in almost half of the cases in type II fractures, while most of the external meniscus tears associated with Schatzker type III and II.

Medial collateral ligaments $(\mathrm{MCL})$ injuries were uniformely distribuited among I, II, V and VI Schatzker type fractures.

Anterior cruciate ligament $(\mathrm{ACL})$ injuries occurred in most cases (6) of significant compression and split fractures (type II, V and VI). A single case was observed in a Schatzker type III fracture.

Avulsion of tibial spines was noted in 5 out of 6 cases of high energy fractures (type IV, V and VI).

\section{Conclusions}

In the last decades, the frequency and severity of tibial plateau fractures has increased, due to road accidents becoming the main cause of their occurrence. In our study, road accidents were responsible for $57.14 \%$ of tibial plateau fractures, outnumbering the total of other causes combined.

In comparison to other fracture sites, imperfect reduction of tibial plateau fractures results more frequently in long term sequellae.

Being frequently complex and comminuted fractures, with associated regional lesions, they raise the complexity of the medical procedures from establishing a complete diagnosis to the final therapeutic measures. From the lot of patients studied, $2 / 3$ of the fractures were associated with various regional lesions.

Schatzker type I, II and III fractures were observed in $65.28 \%$ of cases, which shows the involvement of the external tibial plateau in 2/3 of the cases. The most complex fractures of Schatzker type VI were observed in $5.78 \%$ of cases, their mechanisms of injury being equally distributed between road accidents and falls from height.

For a correct and complete preoperatory diagnosis frequently high performance imaging is needed (MRI, CT, arthroscopy).

Tibial plateau fractures significantly affect patients, the healthcare and social-economic system, during the treatment, healing and rehabilitation period.

The evolution of internal fixation devices and early passive and active knee motion have improved the treatment results of these fractures.

\section{References}

1.HOHL M., Tibial plateau fractures, W.B. Saunders Company Philadelphia, 1997, p. 17-18, 23-30.

2.CANALE T., Campbells operative orthopaedics, vol. III, 9-th ed., Mosby -Year Book, St. -Louis, 1998, p. 2095-2108.

3.BACIU C, DOBRE I., Laxitãple posttraumatice ale genunchiului, Ed. Medicalã, Bucure-ti, 1991, p. 151-154.

4.BENNETT W.F., BROW NER B. - Tibial plateau fractures: a study of associated soft tissue injuries. J. Orthop. Trauma, 8, 1994, p. 903-904.
Table 5

CORRELATION BETWEEN FRACTURE TYPE AND ASSOCIATED REGIONAL INJURIES

\begin{tabular}{|l|c|c|c|c|c|c|}
\hline \multirow{2}{*}{ Associated injury } & \multicolumn{7}{|c|}{ Schatzker } \\
\cline { 2 - 7 } & I & II & III & IV & V & VI \\
\hline \hline Fibula head fracture & 3 & 13 & 4 & - & 4 & 6 \\
\hline EM tears & - & 11 & 12 & - & 3 & 2 \\
\hline MCL lesions & 1 & 3 & - & - & 2 & 1 \\
\hline ACL lesions & - & 2 & 1 & - & 2 & 2 \\
\hline Tibial spines avulsion & - & - & 1 & 2 & 1 & 2 \\
\hline LCL lesions & - & - & - & 2 & - & - \\
\hline PCL lesions & - & - & - & 1 & 1 & - \\
\hline IM tears & - & 1 & 1 & - & - & - \\
\hline \hline Total & $\mathbf{4}$ & $\mathbf{3 0}$ & $\mathbf{1 9}$ & $\mathbf{5}$ & $\mathbf{1 3}$ & $\mathbf{1 3}$ \\
\hline
\end{tabular}

5.TSCHERNE H., LOBENHOFFER P., Tibial plateau fractures management and expected results. Clin. Orthop. 292, 1993, p. 87-100. 6.TATU, R.F., MARSAVINA, L., VOICONI, T., HURMUZ, M., TATU, C., UNGUREAN, C., ROSU, S., Reinforcement of Tibial Fixation in Anterior Cruciate Ligament Reconstruction Using a Polyester Multi Stranded Long Chain Polyethylene Core Suture Material, Mat. Plast., 51, no.4, 2014, p. 460-462

7.PETRESCU H.P., DINU G., NODITI G., CRAINA M., BERCEANU VADUVA D., BERCEANU VADUVA M., VERMESAN D., Morphometric analysis of bone vascular channels during the biointegration of autologous bone grafts, Romanian J. of Morphology and Embriology 54(3), 2013, p. 613616.

8.PETRESCU H.P., DINU G., BERCEANU VADUVA D., BERCEANU VADUVA M., Microdensity and morphometric analysis of autologous bone grafts cells, Romanian J. of Morphology and Embriology 54(2), 2013, p. 395398

9.MARSH J.L., BUCKWALTER J., GELBERMAN R., et al., Articular Fractures: does the anatomic redection realy change the results? J Bone J oint Surg. Am., vol 84 -A, 2002, p. $1259-1271$.

10.PETRESCU, H.P., DINU, G., BERCEANU VADUVA, M., RUSU, L.C., BELENGEANU, D., ARDELEAN, L., BRATU, D.C., Experimental Research on Variation in Serum Calcium, Phosphorus, Sodium, Potassium and the ESR during Bone Transplant, Rev. Chim.(Bucharest), 64, no. 2, 2013, p. 213-217.

11.CIPU, D., BERCEANU VADUVA ,D.M., VELIMIROVICI, D.E., CIPU, D.S., Immunohistochemical Tumor-related Aspects in Diagnostic Mediastinal Lymph Node Extension in Broncho-pulmonary Carcinoma, Rev. Chim. (Bucharest), 67, no. 6, 2016, p.1218-1223.

12.CHAN P.S., KLIMKIENWICZ J.J., LUCHETTY I. et al., Impact of CT scan on treatment plan and fracture clasffication of tibial plateau fractures. J. Orthop. Trauma., 11,1997, p. 7

13.STANCU, A., ROMEO, C., AHMADI, M., CARPINISAN, L., GHISE, A., PENTEA, M., BERCEANU VADUVA, D.M., Hematoxylin - eosinmethylene Blue Staining in a Dog Hemangiosarcoma Case, Mat. Plast., 52, no. 4 , 2015, p. 514-515.

14.PETRESCU H.P., BERCEANU VADUVA M., DINU G., BRATU D.C., BERCEANU VADUVA D., Influence of Implant Material on Electrical Biopotentials in Bone Fractures, Mat. Plast., 50, no.1, 2013, p. 53-55 15.GORUN N., Traumatologie osteoarticulara generala, Ed. Cartea Veche, Bucuresti 2011, p. 79-81.

16.TATU, R,F, ANUSCA, D.N., GROZA, S., MARUSCIAC, L., BOJIN, F.M., TATU, C., HURMUZ, M., PÃUNESCU, V., Morphological and functional characterization of femoral head drilling-derived mesenchymal stem cells, Romanian Journal of Morphology and Embryology, 55, no.4, 2014, p. 1415-1422

17.VERMESAN H., SZILAGYI F., TATU R.F., PETRESCU H., PREJ BEANU R., BERCEANU VADUVA M., Curs de ortopedie, sub redacja Vermesan H., Ed. Mirton, Timisoara, 2001, p. 49-50.

18.VERMESAN H., PRUNDEANU A., TATU R.F., TUDORAN V., PREJ BEANU R., BERCEANU VADUVA M., DELEANU B., COVASANTAN S., Politraumatismele, Ed. a 2-a, Vol. II, sub redacpia Prundeanu A., Vermesan H., Prundeanu H., Editura Mirton, Timi-oara 2001, p. 694698. 
19.DELEANU B., VERMESAN D., HARAGUS H., RADU D., LAZUREANU V., BORZA I., BOIA E., BERCEANU VADUVA M., NICULESCU M., Tehnici chirurgicale in ortopedie si traumatologie, Ed. a 2-a Revizuita, Editura Artpress, Timisoara, Editura Academia de Stiinte Medicale, Bucuresti, 2016, p. 355-368.

20.SCHATZKER J., Tibial Plateau Fractures. In Browner, J upiter, Levine and Trafton -Skeletal Trauma, Philadelphia, W.B. Saunders, 1993, p. 1745.

21.HONKONEN S.E., Fractures of the tibial plateau. Acta Orthop. Scand. Suppl. 284,1999, p. 70.
22.ZLOWODSKI M., KREGOR P.j., COLE P.A., Proximal tibia fractures treated with the LISS system; surgycal experience and clinical results. Eur. Surg. Res. Suppl. 1, 2004, p. 1-148.

23.WEIGEL D.P., MARSH J.L., High energy fractures of the tibial plateau. Knee function after longer folow - up. J. Bone Joint Surg. Am., 84, 2002, p. 1541-1551.

Manuscript received: 2.09 .2018 